Journal of Applied Pharmaceutical Science Vol. 7 (05), pp. 166-173, May, 2017

Available online at http://www.japsonline.com

DOI: $10.7324 / \mathrm{JAPS} .2017 .70529$

ISSN 2231-3354 (cc) BY-NC-SA

\title{
Evaluation of Nootropic Potential of Green Peas in Mice
}

\author{
Sushila Kaura, Milind Parle* \\ Pharmacology Division, Department of Pharmaceutical Sciences, Guru Jambheshwar University of Science \& Technology, Hisar (Haryana) -125001 India.
}

\begin{tabular}{|c|c|}
\hline ARTICLE INFO & ABSTRACT \\
\hline Article history: & Green Peas are tiny powerhouse of nourishment. They are rich in alpha-linolenic acid, flavonoids, carotenoids, \\
\hline Received on: $30 / 11 / 2016$ & phenolic acids, polphenols and pisumsaponins. The present study was employed to assess nootropic potential of \\
\hline Accepted on: 15/03/2017 & Green Peas (Pisum sativum). Elevated Plus Maze model and Passive avoidance Paradigm served as \\
\hline Available online: 30/05/2017 & Exteroceptive Behavioral models. Scopolamine and ethanol were used as amnesic agents. Pisum sativum (PS) in \\
\hline Key words: & $\begin{array}{l}\text { two different concentrations }(2.5 \% \mathrm{w} / \mathrm{w} \text { and } 5 \% \mathrm{w} / \mathrm{w}) \text { were administered with diet, for } 15 \text { successive days to } \\
\text { mice. A decrease in transfer latency and increase in step down latency was observed. Further, green peas }\end{array}$ \\
\hline Pisum sativum, Memory, & ameliorated memory deficits induced by scopolamine and ethanol in mice. PS produced significant increase in \\
\hline Alpha linolenic acid, & brain Glutathione levels, declined brain Malondialdehyde levels and reduced brain Acetylcholinesterase activity. \\
\hline Pisumsaponins, & Therefore, behavioral effects of PS would be worthwhile in management of cognitive dysfunctions. \\
\hline $\begin{array}{l}\text { Neurodegeneration, } \\
\text { Cognitive deficits. }\end{array}$ & \\
\hline
\end{tabular}

\section{INTRODUCTION}

For all age groups cognition is important. Loss of memory affects most basic activities of daily living. With the growing impact of progressive neurodegenerative diseases like Alzheimer, new treatments need to be developed that could effectively improve the cognitive and physical performance of patients. At present, most of the allopathic medicines exhibit side effects, when taken for long term. Thus, it is the important to focus on a dietary component that is easily available as well as acceptable to patients. In addition to this, it should also improve learning and memory in patients suffering from cognitive dysfunctions. Green Peas are storehouse of energy. Protein

\footnotetext{
* Corresponding Author

Milind Parle, Dean Faculty of Medical Sciences Professor of Pharmacology Department of Pharmaceutical Sciences Guru Jambheshwar University of Science and Technology Hisar

(Haryana) -125001 India. Email: mparle @ rediffmail.com
}

(Ali Khan and Young, 1973), fiber and micronutrients present in peas facilitate weight management. They also possess antioxidant activity due to abundant flavonoids, carotenoids and polyphenols. Saponins (Price et al., 1986) like Pisumsaponins I \& II and pisomosides A \& B (Murakami et al., 2001) are the natural antiinflammatory agent exclusively found in peas. In addition to this, green peas have good amount of Vitamin C, B, E and $\mathrm{K}$ (Patwardhan, 1962) as well as mineral zinc (Lopez et al., 1986). Furthermore, Omega-3 fatty acids in the form of alpha-linolenic acid (ALA) are also reported in peas (Andrzejewska et al., 2015). Presence of all such bioactive constituents in green peas makes them valuable for managing memory impairments. Furthermore, they could have protective role in age-related decline in Alzheimer's disease.

But till date, there is no strong evidence supporting memory enhancing activity of green peas. Hence, the current research work was designed to explore the Nootropic Potential of Green peas by applying different interoceptive and exteroceptive behavioral models. 


\section{MATERIALS AND METHODS}

\section{Plant material}

Green peas (Pisum sativum) were procured from Department of Pulses, College of Agriculture, Haryana Agriculture University (HAU), Hisar, Haryana, India.

\section{Animals}

A total of 126 Swiss mice were employed for the present study. Young mice, 3-4 months old, weighing around $22 \mathrm{~g}$, were obtained from the Disease Free Small Animal House, Lala Lajpat Rai University of Veterinary Sciences, (LUVAS) Hisar (Haryana). The Institutional Animals Ethical Committee (IAEC) approved the experimental protocol and the care of animals was taken as per guidelines of CPCSEA, Ministry of Forests and Environment, Government of India (Registration number 0436). All the animals were acclimatized for seven days before starting the experimental studies

\section{Drugs}

Piracetam was purchased from Intas Pharmaceuticals Ltd. Ahmedabad India, Donepezil and Scopolamine were obtained from Sigma Aldrich. Ethanol was procured from Changshu Yangyuan Chemical, China. Biochemical studies were carried on $16^{\text {th }}$ day, 90 min after drugs/vehicle/Pisum sativum administration.

\section{Experimental design}

Group I: Control group for young mice received vehicle only.

Group II: Positive control received Piracetam (400mg/kg, i.p) for 15 consecutive days.

Group III: Positive control received Donepezil ( $1 \mathrm{mg} / \mathrm{kg}$, i.p) for 15 consecutive days.

Groups IV: Young mice were administered fresh Pisum sativum paste $(2.5 \% \mathrm{w} / \mathrm{w})$ orally along with diet for 15 consecutive days.

Groups V: Young mice were administered fresh Pisum sativum paste $(5 \% \mathrm{w} / \mathrm{w})$ orally along with diet for 15 consecutive days.

Group VI: Young mice were injected with Scopolamine $(0.4 \mathrm{mg} / \mathrm{kg}$ i.p) on 14th day.

Group VII: Piracetam (400mg/kg i.p) was injected to young mice for fifteen consecutive days. At $60 \mathrm{~min}$ after injection of Piracetam on 14th day, Scopolamine was injected. Mice were exposed to training session $45 \mathrm{~min}$ after injection and retention memory examined after $24 \mathrm{~h}$.

Groups VIII: PS $(2.5 \% \mathrm{w} / \mathrm{w})$ was administered orally along with diet for 15 consecutive days. Scopolamine $(0.4 \mathrm{mg} / \mathrm{kg}$ i.p) was injected to young mice at $90 \mathrm{~min}$ after administration of PS on 14th day. Mice were exposed to training session $45 \mathrm{~min}$ after injection and retention memory examined after $24 \mathrm{~h}$.

Group IX: Ethanol treated group was injected with Ethanol ( $2.5 \mathrm{~g} / \mathrm{kg}$ i.p) on 14 th day into young mice.
Group X: Piracetam (400mg/kg i.p) was injected to young mice for fifteen consecutive days. $60 \mathrm{~min}$ after injection of Piracetam on 14th day, Ethanol was injected. Mice were exposed to training session 30 min after injection and retention memory was examined after $24 \mathrm{~h}$ (i.e. on 15th day).

Groups XI: PS $2.5 \% \mathrm{w} / \mathrm{w}$ was administered orally along with diet for 15 consecutive days. Ethanol $(2.5 \mathrm{~g} / \mathrm{kg}$ i.p) was injected to young mice at $90 \mathrm{~min}$ after administration of PS on 14th day. Mice were exposed to training session $30 \mathrm{~min}$ after injection and retention memory was examined after $24 \mathrm{~h}$.

Above grouping was repeated for Passive Avoidance Paradigm except Group III (Donepezil Group) leading to a total of 21 groups.

\section{Behavioral Models \\ Elevated Plus Maze (EPM)}

EPM is one of the exteroceptive behavioral models, that is most frequently employed to examine short-term memory in rodents. It consists of two open arms measuring $16 \mathrm{~cm}$ x $5 \mathrm{~cm}$ and two covered arms of dimension $16 \times 5 \mathrm{~cm} \times 12 \mathrm{~cm}$, for mice. Both the arms are extended from a central platform $(5 \mathrm{~cm} \times 5 \mathrm{~cm})$. EPM is raised to a height of $25 \mathrm{~cm}$ from the ground. On the first day ( $14^{\text {th }}$ day of administration of PS), every mouse was kept at the end of one of the open arm but facing away from the central platform for knowing acquisition Transfer Latency (TL). TL is the time taken by mouse to move into a covered arm with all its four legs. TL was assigned as $90 \mathrm{sec}$ in case mice do not enter into any of the covered arms within $90 \mathrm{sec}$.

It is then gently pushed into one of the two covered arms and allowed to explore the maze for $10 \mathrm{sec}$. After that mouse was returned to home cage. Retention was examined 24 hours after the first day's trial (Parle and Singh, 2004; Vasudevan and Parle, 2006).

\section{Passive Avoidance Paradigm}

Passive avoidance behavior (Step Down), based on negative reinforcement, is used to evaluate the long term memory in mice. The equipment consists of a box of dimension $27 \times 27 \times$ $27 \mathrm{~cm}^{3}$. It has three walls of wood and one wall of Plexiglas. At the base it has a grid floor having $3 \mathrm{~mm}$ stainless steel rods that set $8 \mathrm{~mm}$ apart, with a wooden platform $\left(10 \times 7 \times 1.7 \mathrm{~cm}^{3}\right)$ in the center of the grid floor. Electric shock (20V AC) was delivered to the grid floor.

The box remains illuminated with a $15 \mathrm{~W}$ bulb during the experiment. Each mouse was gently placed on the wooden platform. When the mouse stepped down and placed all its paws on the grid floor, shocks were delivered for $5 \mathrm{sec}$ and the stepdown latency (SDL) was recorded. SDL is defined as the time taken by the mouse to step down from wooden platform to grid floor with its entire paw on the grid floor. Retention was tested after $24 \mathrm{~h}$ in a similar manner, except that the electric shocks were 
not applied to the grid floor, with an upper cut-off time of $300 \mathrm{sec}$. (Joshi and Parle, 2005; Joshi and Parle, 2006).

\section{Interoceptive behavioral models}

Scopolamine and ethanol were employed as amnesic agents in the present study.

\section{Biochemical estimations}

The mice were decapitated. Their whole brain was dissected out on $16^{\text {th }}$ day and utilized for Acetylcholinestrease, GSH and TBARS estimations.

\section{Estimation of whole brain acetylcholinesterase (AchE)}

It is carried out based on Ellman's method with slight modifications. Whole brains of mice placed instantaneously in icecold saline. It is then weighed and homogenized in $10 \% \mathrm{w} / \mathrm{v} 0.1 \mathrm{M}$ Phosphate buffer ( $\mathrm{pH} 8$ ). The sample was then centrifuged for 10 min at $10,000 \mathrm{rpm}$. $0.4 \mathrm{~mL}$ of the supernatant is added to $2.6 \mathrm{~mL}$ $0.1 \mathrm{M}$ phosphate buffer $(\mathrm{pH} 8)$ and $0.1 \mathrm{~mL}$ of 5, 5'-dithiobis 2nitro benzoic acid (DTNB) mixture. The contents are mixed. Absorbance is measured at $412 \mathrm{~nm}$ in a spectrophotometer. When absorbance reaches a stable figure value, it is recorded as the basal reading. $0.02 \mathrm{~mL}$ acetylthiocholine is added and change in absorbance is recorded after period of $15 \mathrm{~min}$ ( Ellman et al., 1964; Biradar et al., 2013):

$\mathrm{R}=\delta$ O.D X Volume of Assay $(3 \mathrm{ml}) / \mathrm{E} \mathrm{X} \mathrm{mg} \mathrm{of} \mathrm{Protein}$

Where, R- Rate of enzyme activity in ' $n$ ' mole of acetylcholine iodide hydrolyzed $/ \mathrm{min} / \mathrm{mg}$ of protein, $\delta$ O.D Change in absorbance/min and E- Extinction coefficient$13,600 / \mathrm{M} / \mathrm{cm}$.

\section{Determination of reduced glutathione (GSH) levels}

Whole brain of mice was homogenized in $0.1 \mathrm{M}$ phosphate buffer ( $\mathrm{pH} 7.4$ ) 10\% w/v in ice cool environment. This brain homogenate was precipitated with the $4 \%$ trichloroacetic acid (1:1). The sample was then centrifuged at $5000 \mathrm{rpm}$ for 10 minutes at $4^{\circ} \mathrm{C}$ using refrigerated centrifuge (Remi instruments, Mumbai, India). $2 \mathrm{ml}$ of $0.3 \mathrm{M}$ disodium hydrogen phosphate buffer ( $\mathrm{pH} \mathrm{8.4)}$ and $0.4 \mathrm{ml}$ of double distilled water was added to $0.5 \mathrm{ml}$ of supernatant obtained. Then $0.25 \mathrm{ml}$ of freshly prepared
DTNB $(0.001 \mathrm{M})$ dissolved in $1 \% \mathrm{w} / \mathrm{v}$ sodium citrate was added to the above reaction mixture. The reaction mixture was incubated at room temperature for $10 \mathrm{~min}$. The developed yellow colour was read immediately at $412 \mathrm{~nm}$ using UV-Visible Spectrophotometer. (Ellman, 1959), The reduced glutathione concentration was calculated as $\mu$ moles $\mathrm{GSH} / \mathrm{mg}$ protein using a molar extinction coefficient of GSH is $1.36 \times 10^{4} \mathrm{M}^{-1} \mathrm{~cm}^{-1}$ (Yousuf et al., 2005).

\section{Determination of malondialdehyde (MDA) levels}

Whole brain of mice was homogenized in $0.1 \mathrm{M}$ phosphate buffer ( $\mathrm{pH} 7.4$ ) $10 \% \mathrm{w} / \mathrm{v}$ in ice cool environment. The homogenate was mixed with tris $-\mathrm{HCl}(\mathrm{pH} 7.4)$ in ratio of $1: 1$. The reaction mixture was incubated for two hours at $37^{\circ} \mathrm{C}$. It is then centrifuged at $1000 \mathrm{rpm}$ for 10 minutes after adding $1 \mathrm{ml}$ of Trichloro acetic acid (TCA $10 \%$ ice cold). $1 \mathrm{~mL}$ of clear supernatant solution obtained was then mixed with $1 \mathrm{~mL}$ of freshly prepared Thiobarbituric Acid (TBA 0.67\%).

This solution was heated for $10 \mathrm{~min}$ in a boiling water bath. It was instantaneously cooled for $5 \mathrm{~min}$ in cold water and $1 \mathrm{ml}$ of Double Distilled Water was added. The developed color was measured at $532 \mathrm{~nm}$ against blank. (Wills, 1964) MDA levels were quantified using an extinction coefficient of $1.56 \times 10^{5} \mathrm{M}^{-1}$ $\mathrm{cm}^{-1}$.

\section{RESULTS \\ Effect of Pisum Sativum (PS) on Transfer Latency (TL) of Mice}

Pisum sativum (PS) administered animals have shown significant $(\mathrm{p}<0.01)$ decrease in TL compared to the control group of mice in Elevated Plus Maze (EPM) model. Thus, PS alone has produced remarkable improvement in memory in dose dependent manner $2.5 \% \mathrm{w} / \mathrm{w}(\mathrm{p}<0.01)$ and $5 \% \mathrm{w} / \mathrm{w}(\mathrm{p}<0.05)$. These results are comparable to the memory enhancing effect of both Piracetam $(\mathrm{p}<0.01)$ and Donepezil $(\mathrm{p}<0.01)$. Furthermore, memory deficits induced by Scopolamine and Ethanol were successfully reversed by pre-treatment of PS at $2.5 \%$ w/w concentration. Being a standard nootropic agent Piracetam also reversed the memory impairment $(\mathrm{p}<0.01)$ produced by Scopolamine and Ethanol (Fig. $1)$.

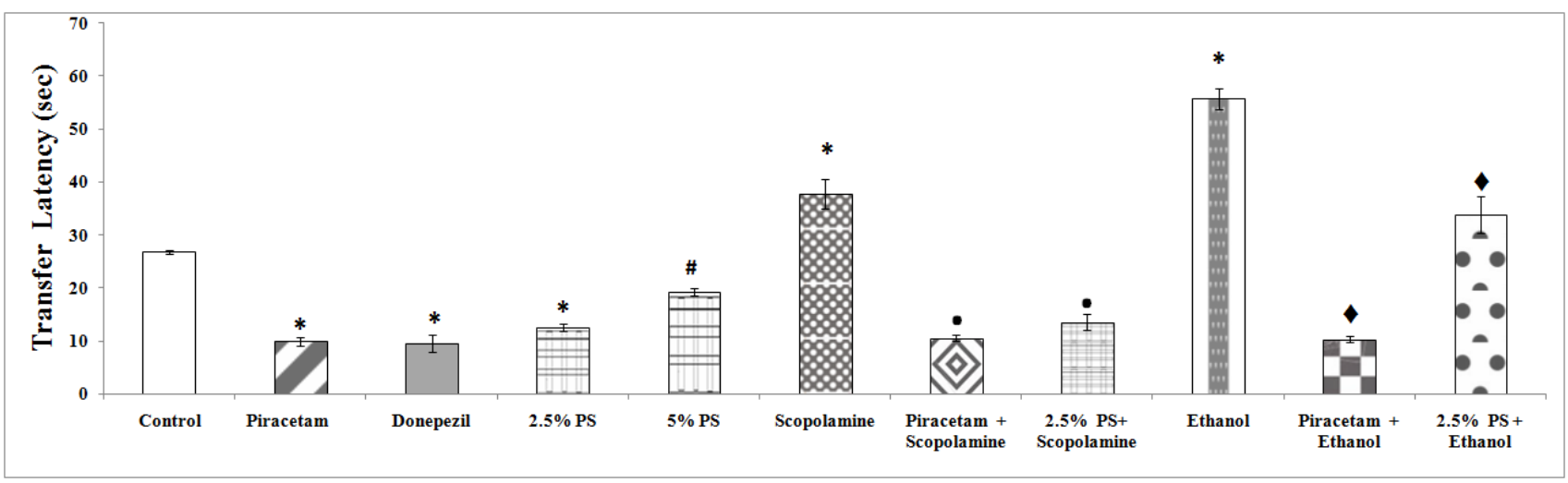

Fig. 1: Effect of Pisum sativum on Transfer Latency of Mice Using Elevated Plus Maze. * denotes $p<0.01$ as compared to Control group; - denotes $\mathrm{p}<0.01$ as compared to Scopolamine group alone; 


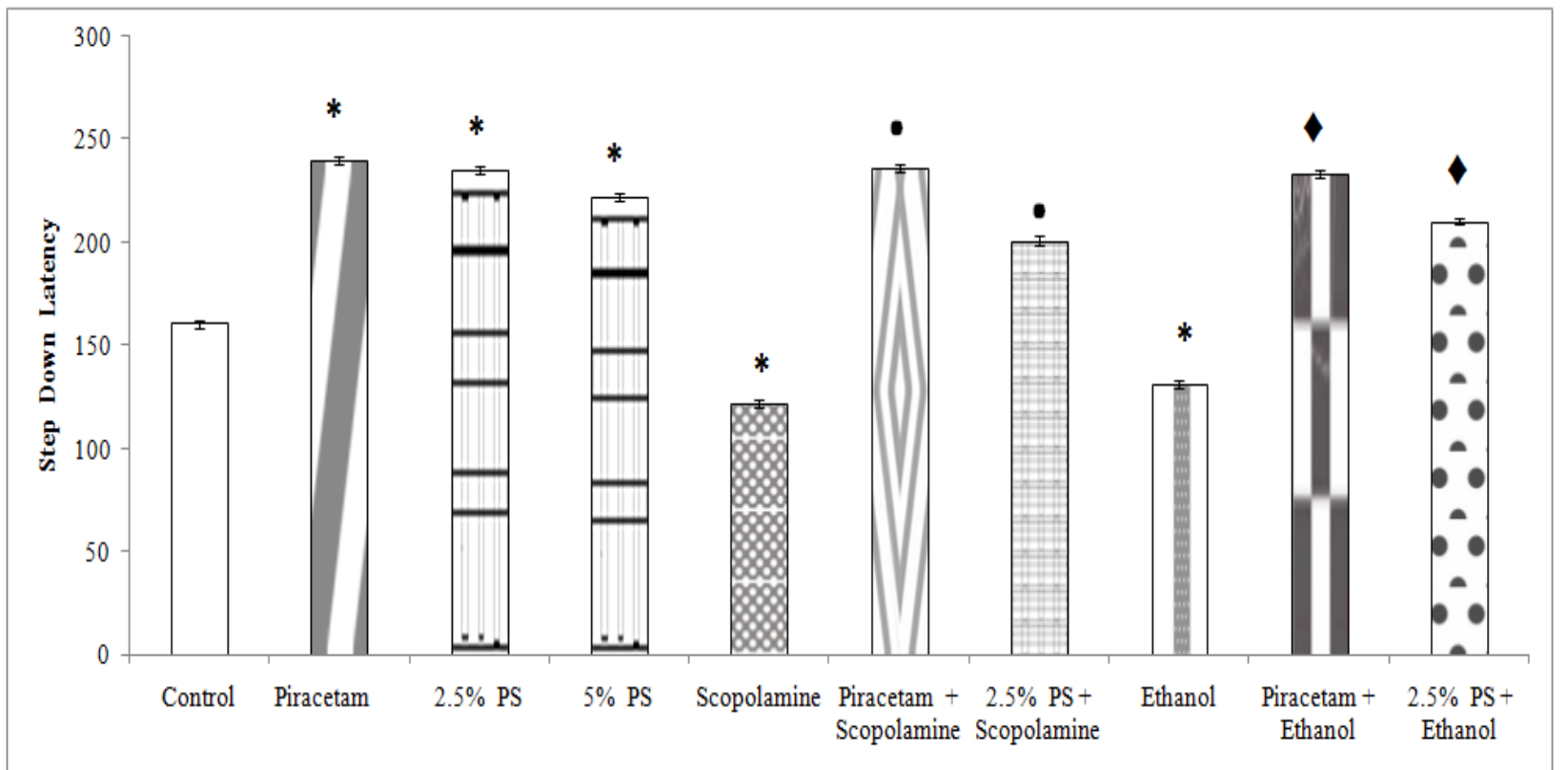

Fig. 2: Effect of Pisum sativum on Step Down Latency of mice using Passive Avoidance Paradigm.

* denotes $p<0.01$ as compared to Control group; - denotes $\mathrm{p}<0.01$ as compared to Scopolamine group alone; - denotes $\mathrm{p}<0.01$ as compared to Ethanol group alone.

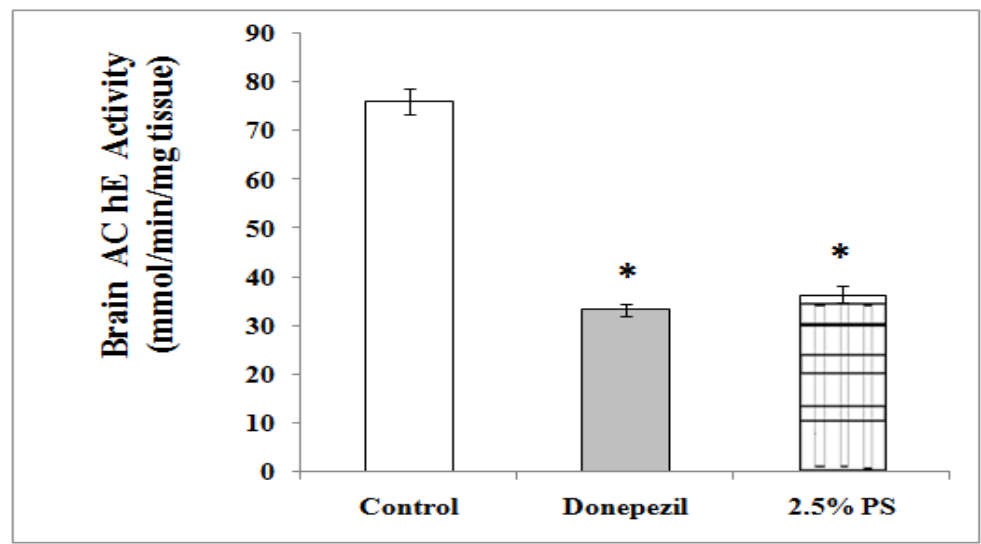

Fig. 3: Influence of Pisum sativum on Brain Acetylcholinesterase Activity.

* denotes $p<0.01$ as compared to Control group.

\section{Effect of Pisum Sativum (PS) on Step Down Latency (SDL) of Mice}

There was a remarkable improvement $(\mathrm{p}<0.01)$ in memory scores in PS administered animals compared to the control group. This is clear from the fact that mice administered with $2.5 \%(\mathrm{p}<0.01)$ and $5 \%(\mathrm{p}<0.05)$ w/w PS have increased the SDL in Passive Avoidance Paradigm. Memory enhancement was comparable to that of standard nootropic agent Piracetam $(\mathrm{p}<0.01)$. In addition to this, Scopolamine induced amnesia was significantly $(\mathrm{p}<0.01)$ reversed by pre- treatment of PS at $2.5 \% \mathrm{w} / \mathrm{w}$ dose. Moreover, piracetam also reversed scopolamine induced memory deficits as expected (Fig. 2).

\section{Whole brain acetylcholinesterase (AchE) activity}

Pisum Sativum (PS) alone at $2.5 \% \mathrm{w} / \mathrm{w}$ concentration reduced the AchE activity significantly $(\mathrm{p}<0.01)$ in comparison to the control group. Donepezil being a standard Acetylcholinesterase inhibitor successfully $(\mathrm{p}<0.01)$ decreased the AchE activity in mice. PS at 5\% w/w concentration reduces the AchE activity but it is insignificant $(\mathrm{p}>0.05)$ in comparison to the control group (Fig. $3)$.

\section{Whole brain Glutathione (GSH) levels}

PS per se group significantly raised GSH levels compared to normal group in dose dependent manner $2.5 \% \mathrm{w} / \mathrm{w}$ $(\mathrm{p}<0.01)$ and $5 \% \mathrm{w} / \mathrm{w}(\mathrm{p}<0.05)$ (Fig. 4).

\section{Whole brain Malondialdehyde (MDA) levels}

There was successful reduction in MDA levels compared to control group in dose dependent manner $2.5 \% \mathrm{w} / \mathrm{w}(\mathrm{p}<0.01)$ and $5 \%$ w/w $(\mathrm{p}<0.05)$ (Fig. 5). 


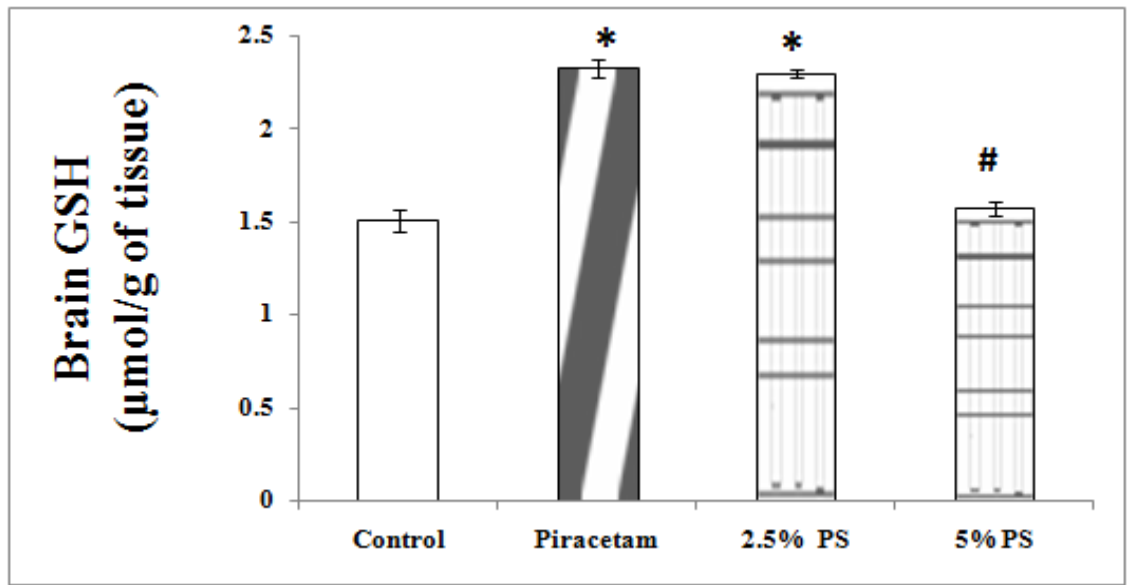

Fig. 4: Influence of Pisum sativum on Brain Glutathione levels.

* denotes $p<0.01$ as compared to Control group; \# denotes $\mathrm{p}<0.05$ as compared to Control

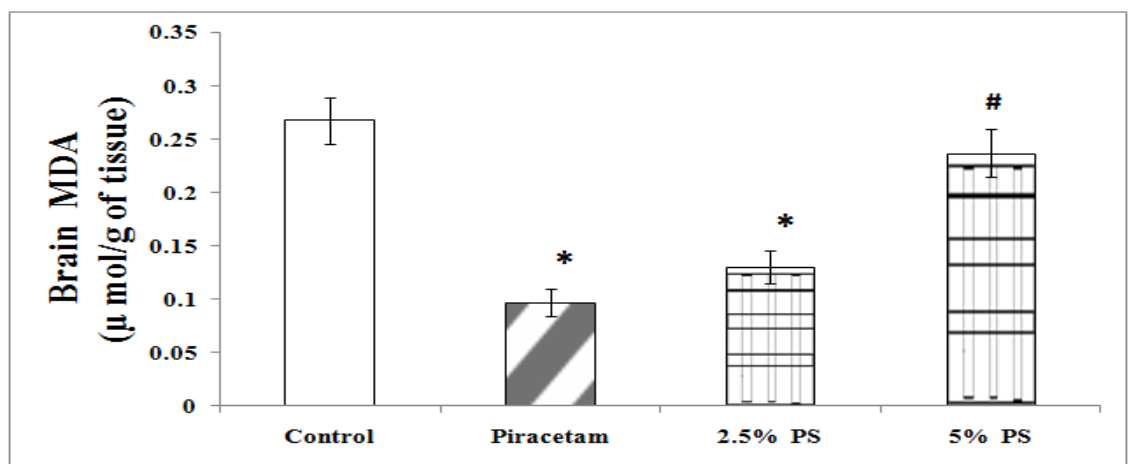

Fig. 5: Effect of Pisum sativum on Brain Malondialdehyde level.

* denotes $p<0.01$ as compared to Control group; \# denotes $\mathrm{p}<0.05$ as compared to Control

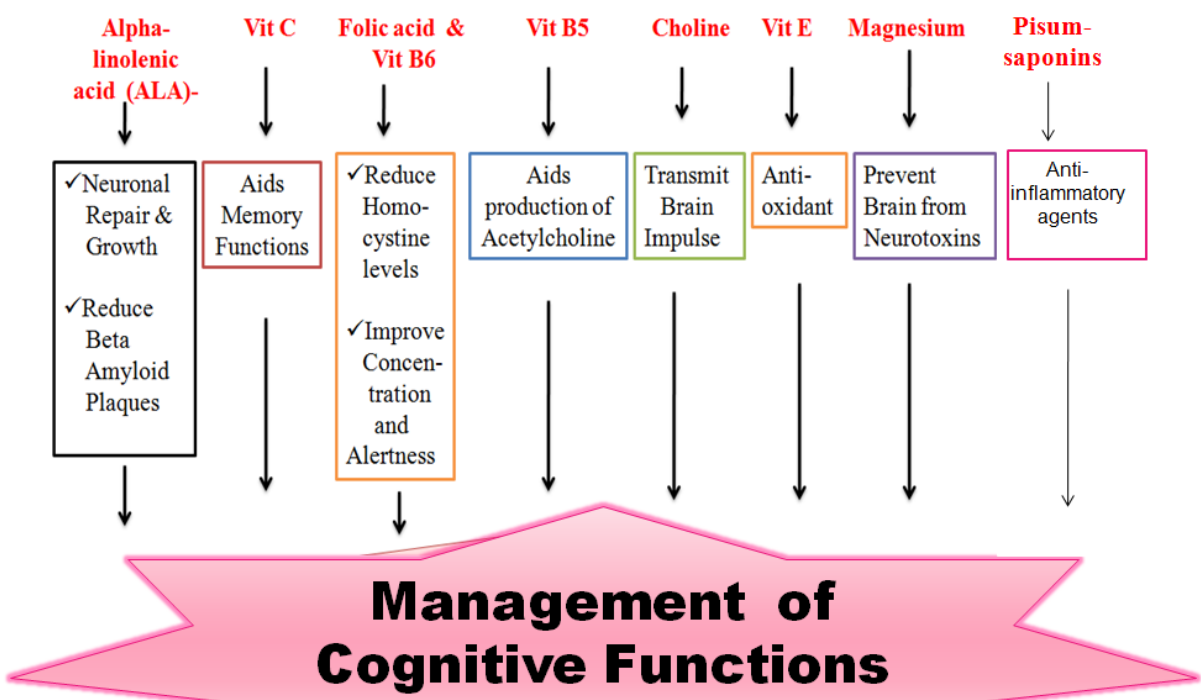

Fig. 6: Possible Mechanism of action of Green Peas. 


\section{DISCUSSION}

We are what our memory is. It is a collection that encode, store, retain, and later retrieve the information. The fundamental types of memory are sensory, short term and long term memory. Short-term memory (STM) stores temporary information. Manipulation of the temporary stored information is done by working memory. Rehearsing / repeating the information in STM, transfers that information into the long-term memory (LTM). The capability to infiltrate and recapture information from LTM, let us make judgments and resolve dilemma. LTM has unlimited storage capacity. It is for this reason we could gain new knowledge and skills whole life leading to a permanent change in the neuronal network (learning). This slows down the process of aging/ memory loss. Thus, learning and memory are two elementary cognitive functions, which build up our intellectual capacity from our experience. Aging, depression and glitches are the conditions that may lead to either temporary or permanent memory loss. A majority of population lack the basic understanding of the memory loss due to lack of information and awareness. So, it becomes hard to even diagnose it. Thus, documentation of the disease remains incomplete. Several medications are available to treat memory loss such as piracetam, donepezil etc. These drugs are effective for some but not all people, and may help only for a limited time. Clinical trials are being conducted by scientists to develop and test numerous possible interventions which surely have side effects. Therefore, we conducted the present research to lay emphasis on the use of easily available nutrient i.e. Green Peas to prevent as well as cure memory deficits. In this study we have employed Elevated Plus Maze model for measuring short term memory and Passive Avoidance Paradigm for measuring long term memory in mice. In both the models we found that memory was enhanced surprisingly in mice consuming $2.5 \%$ and $5 \% \mathrm{w} / \mathrm{w}$ of Pisum sativum. Studies in animals have proved that alcohol consumption decrease the count of cholinergic neurons in forebrain region of brain, consequently reducing function of hippocampus and other brain structures (Devi and Ramasubramaniaraja, 2009). Thus, Ethanol impairs learning and memory by inducing neurodegeneration in animals. In our study amnesic effect of ethanol was significantly reversed by $2.5 \%$ of Pisum sativum in mice. Apart from Ethanol, Scopolamine is also an amnesic agent that is useful In vivo Interoceptive model for Alzheimer's disease. It has been widely employed in research for screening of nootropic potential of various drugs. It impedes the cognitive function by obstructing muscarinic cholinergic receptors in human beings as well as in laboratory animals (Rubio et al., 2007). Cognitive deficit are also amplified by increase in acetylcholinesterase (AChE) levels after administration of scopolamine (Kwon et al., 2010). Also, scopolamine-induced animal model has shown to increase levels of $\mathrm{A} \beta$ and elicit oxidative stress in the rodent brain (Choi et al., 2012). Here, mice injected with scopolamine exhibited longer Transfer Latency (Elevated Plus Maze) and shorter Step Down Latency (Passive Avoidance Paradigm) in comparison to control group of mice.
Administration of $2.5 \%$ of Pisum sativum in mice for 15 successive days remarkably reversed memory deficits/amnesia induced by Scopolamine.

Cognition is considered to be regulated by acetylcholine (Ach) (Bartus et al., 1982). Ach is regarded as the major neurotransmitter involved in regulation of learning ability and memory (Parle and Kaura, 2013). Acetylcholinesterase (AChE) is an enzyme, which terminates the action of Ach. Loss of acetylcholine in hippocampus area occurs in the patients of $\mathrm{AD}$ (Kaura and Parle, 2015). The gradual death of brain cells chiefly cholinergic neurons and subsequent decline in the acetylcholine levels is the key characteristic of neurodegenerative diseases. Pisum sativum has sufficient amount of choline. It also contains vitamin B5 (Patwardhan, 1962) that aids production of choline. Hence, Pisum sativum could have impact on the central cholinergic activity.

Numerous pathological progressions such as inflammation, age-related diseases, neurodegenerative disorders, atherosclerosis etc., are due to the occurrence of oxygen free radicals (OFR) inside and outside cells (Birkner et al., 2004; Valko et al., 2007). OFR straightforwardly react with DNA, lipids and proteins and results in improper enzymatic activitiy, cell mutations, apoptosis, (Halliwell and Gutteridge, 1993) protein injury, nucleic acids damage and lipid peroxidation (Prabha et al., 1990). The process of oxidative decomposition of polyunsaturated fatty acids (PUFA) of membrane phospholipids is called lipid peroxidation. Malondialdehyde (MDA) is an aldehydic end product of lipid peroxidation (Kaura and Parle, 2015). The cytopathological effects observed during oxidative stress of lipid peroxidation are mainly due to MDA. Brain lipid bilayer is rich in PUFA and oxygen due to which, it is highly susceptible to lipid peroxidation (Kaura and Parle, 2015). OFR attack PUFA in brain cells leading to oxidative lesions that has an important role in the pathogenesis of age related neurological diseases like Alzheimer's disease. In addition to this, Alzheimer is also a consequence of oxidative stress (Srinivasan, 2002). Glutathione (GSH) is called mother of all antioxidants (Fernández-Chec et al., 1997) that prevent oxidative stress. GSH is produced and recycled naturally all the time in the body. It is a combination of three amino acids -cysteine, glycine and glutamine (Shelly and Lu, 2009). This master detoxifier has the capability of regenerating other antioxidants, such as vitamins $\mathrm{C}$ and $\mathrm{E}$. Toxins are passed around from vitamin $\mathrm{C}$ to vitamin $\mathrm{E}$ and to lipoic acid. Then these free radicals stick onto sulphur group of glutathione, which then carries them into the bile and stool that are excreted out of the body. Now body can regenerate another protective glutathione. Under normal conditions glutathione is recycled in the body. But trouble arises, when we are overloaded with too much oxidative stress resulting in chronic illness (Nuttall et al., 1998). Brain uses a lot of oxygen, and generates lot of oxidative stress. Therefore, maintaining glutathione levels in the brain is crucial. Low glutathione levels show a closed link to learning. Hence, Oxidative stress is exhibited by increased MDA and decreased GSH levels indicating the decline in antioxidant enzymatic activity (Behl, 1999; Pratico, 
2008). This decreased antioxidant activity was significantly raised by Pisum sativum in dose dependant manner by increasing the levels of GSH and decreasing the levels of MDA. Moreover, presence of folate, vitamins B6 (methylation nutrients), vitamins C and E, aids recycling of GSH. Green peas have these nutrients (Patwardhan, 1962) due to which antioxidant activity is further augumented (Fig. 6). Moreover, Green Peas are rich in pisumsaponins (Murakami et al., 2001). Saponins have been reported to possess cholesterol lowering effects (Oakenfull, 1981). Further, they are good anti-inflammatory agents and also enhance immunity. In addition to this, Green Peas have Alpha- linolenic acid (Andrzejewska et al., 2015), a form of omega -3-fatty acids that is essential for growth and development of human body. Dietary supplementation with essential fatty acids such as omega 3 fatty acids was shown to improve membrane fluidity, neuronal function and neuroprotection (Kumar and Khanum, 2012). Therefore, in consideration of the above findings, it would be productive to investigate clinically the efficacy of Green peas in managing cognitive deficits.

\section{CONCLUSION}

Green peas produced powerful nootropic effect in excteroceptive as well as interoceptive behavioural models in the present study. Further, memory deficits induced by scopolamine and ethanol were also reversed in mice administered with Pisum sativum, with diet for 15 days. It is remarkable to note that green peas contain good amount of alpha linoleic acid, pisumsaponins and Vitamin B, E \& C, which plays an important role in learning and memory. The results of the current research work ultimately reveals antioxidant and anti-cholinesterase characteristic of green peas that is indicated by increase in GSH level, decrease in the MDA and decline in acetylcholinesterase activity, respectively. Hence, behavioral effects of PS might prove potential in managing cognitive dysfunctions.

\section{ACKNOWLEDGMENTS}

Financial support and sponsorship: Ms. Sushila Kaura is an Inspire Research Fellow of DST, Government of India, New Delhi.

Conflict of Interests: There are no conflicts of interest.

\section{REFERENCES}

Ali Khan ST, Young CG. Variation in Protein content of field peas. Can. J. Plant Sci., 1973; 53: 37-41.

Andrzejewska J, Ignaczak S, Katańska-Kaczmarek A, Barzyk P. Crude Fat Content And Fatty Acid Profile In The Seeds Of Polish Lines And Cultivars Of Field Pea (Pisum Sativum L.): Pilot Study, EJPAU, 2015; 18(4), \#07.

Behl C. Alzheimer's disease and oxidative stress: Implications for novel therapeutic approaches. Prog. Neurobiol. 1999; 57: 301-323.

Bartus RT. 2000. On neurodegenerative diseases, models, and treatment strategies: lessons learned and lessons forgotten a generation following the cholinergic hypothesis. Exp. Neurol. 163: 495-529.
Birkner E, Zalejska-Fiolka J, Antoszewski Z: Antioxidant enzymes activity and role of antioxidant vitamins in Alzheimer disease. Post Hig Med Dosw, 2004; 58: 264-69.

Biradar SM, Joshi H, Tarak KC. Cerebroprotective Effect of Isolated Harmine Alkaloids Extracts of Seeds of Peganum harmala L. on Sodium Nitrite-induced Hypoxia and Ethanol-induced Neurodegeneration in Young Mice. Pak J Biol Sci, 2013 16: 1687-97.

Choi DY, Lee YJ, Lee SY, Lee YM, Lee HH, Choi IS, et al. Attenuation of scopolamine-induced cognitive dysfunction by obovatol. Arch Pharm Res, 2012; 35:1279-86.

Devi PB and R Ramasubramaniaraja. Dental caries and medicinal plants-an overview. J. Pharm. Res, 2009; 2: 1669-75.

Ellman G. Tissue sulphydryl groups. Arch Biochem Biophys, 1959; 82: 70-3.

Ellman GL, Courtney KD, Andres V, Jr. Feather-Stone RM. A new and rapid colorimetric determination of acetylcholinesterase activity. Biochem Pharmacol, 1961; 7: 88-95.

Fernández-Checa J, Kaplowitz N, Garcia-Ruiz C, Colell A, Miranda M, Mai M, Ardite E, Morales A. GSH transport in mitochondria: defense against TNF-induced oxidative stress and alcohol-induced defect. Am J Physiol 1997; 273: G7-G17.

Halliwell B, Gutteridge JM: Free radicals in biology and medicine. Clarendon Press, Oxford, 1993; 86-187

Joshi H, M Parle. Effects of piperine on memory and behavior mediated via monoamine neurotransmitters. J. Tradit. Med, 2005; 22: 39 43.

Joshi H, M Parle. Nardostachys jatamansi improves learning and memory in mice. J. Med. Food, 2006; 9: 113-8.

Kumar GP, Khanum F. Neuroprotective potential of Phytochemicals. Phcog rev, 2012; 6: 81-90.

Kwon SH, Lee HK, Kim JA, Hong SI, Kim HC, Jo TH, et al. Neuroprotective effects of chlorogenic acid on scopolamine-induced amnesia via anti-acetylcholinesterase and anti-oxidative activities in mice. Eur J Pharmacol, 2010; 649: 210-7.

Kaura S, Parle M. Anti-Alzheimer potential of Green Moong Bean. Int. J. Pharm. Sci. Rev. Res, 2015; 37(2): 178-182.

Lopez A, Williams HL, Cooler FW. Essential elements and cadmium and lead in fresh and canned peas (Pisum sativum L). J. Food Sci., 1986; 51: 604-607.

Murakami T, Kohno K, Matsuda $\mathrm{H}$, and Yoshikawa $\mathrm{M}$. Medicinal Foodstuffs. XXII.1) Structures of Oleanane-Type Triterpene Oligoglycosides, Pisumsaponins I and II, and Kaurane-Type Diterpene Oligoglycosides, Pisumosides A and B, from Green Peas, the I mmature Seeds of Pisum sativum L. Chem. Pharm. Bull, 2001; 49(1): $73-7$.

Nuttall S, Martin U, Sinclair A, Kendall M. Glutathione: in sickness and in health. The Lancet, 1998; 351(9103):645-646.

Okhawa H, Ohishi N, Yagi K. 1979. Assay of lipid peroxidase in animals tissue by thiobarbituric acid reaction. Anal Biochem 95: 351358.

$19-40$.

Oakenfull D. Saponin in food- A review. Food Chem, 1981; 7:

Patwardhan VN. Pulses and beans in human nutrition. Am J Clin Nutr, 1962; 11: 12-30.

Price KR, Curl CL, Fenwick GR. The saponin content and sapogenol composition of the seed of 13 varieties of legume. J Sci Food Agr, 1986; 37: 1185-91.

Prabha PS, Das UN, Koratkar R et al.: Free radical generation, lipid peroxidation and essential fatty acids in uncontrolled essential hypertension. Prostaglandis Leukot Essent Fatty Acids, 1990; 41: $27-33$

Parle M, N Singh. Animal models for testing memory. Asia Pac. J. Pharmacol, 2004; 16: 101-20.

Pratico, D. Oxidative stress hypothesis in Alzheimer's disease: A reappraisal. Trends Pharmacol. Sci, 2008; 29: 609-615.

Parle M, Kaura S. Green Chilli : a memory Booster from nature. Annals of Pharmacy and Pharmaceutical Sciences, 2013; 4(1-2): 17-21.

Rubio J, Dang H , Gong M, Liu X, Chen S, Gustavo F. Food and Chemical Toxicology 2007; 45: 1882-90. 
Srinivasan V. Melatonin oxidative stress and neurodegenerative diseases. Ind. J. Exp. Biol, 2002; 40: 668-79.

Shelly C, Lu MD. Regulation of Glutathione Synthesis. Mol Aspects Med. 2009; 30 (1-2): 42-59.

Vasudevan $M$ and $M$ Parle. Pharmacological action of Thespesia populnea relevant to Alzheimer's disease. Phytomedicine, 2006; 13: 677-87.

Valko M, Leibfritz D, Moncol $\mathrm{J}$ et al.: Free radicals and antioxidants in normal physiological functions and human disease. Int $\mathbf{J}$ Biochem Cell Biol, 2007; 39(1): 44-84

Wills ED. The effect of inorganic iron on the thiobarbituric acid method for the determination of lipid peroxides. Biochim. Biophys. Acta 1964; 84: 475-77.
Yousuf S, Salim S, Ahmad M, Ahmed AS, Ansari MA, F Islam. Protective effect of Khamira Abresham Uood Mastagiwalaagainst free radical induced damage in focal cerebral ischemia. J. Ethnopharmacol, 2005; 99: 179-84.

\section{How to cite this article:}

Kaura S, Parle M. Evaluation of Nootropic Potential of Green Peas in Mice. J App Pharm Sci, 2017; 7 (05): 166-173. 